\title{
KEPUTUSAN INVESTASI, KEPUTUSAN PENDANAAN DAN KEBIJAKAN DIVIDEN SEBAGAI DETERMINAN NILAI PERUSAHAAN
}

\author{
Oleh : \\ Heri Setiyo Cahyono \\ Ardiani Ika Sulistyawati \\ Email : ardiani.ika2005@gmail.com \\ Fakultas Ekonomi Universitas Semarang
}

\begin{abstract}
Optimization of the company's value can be achieved through the implementation of the financial management function, where the financial decisions taken will affect other financial decisions and have an impact on the value of the company's financial management regarding the settlement of the important decisions taken by the company. This study aimed to analyze the influence investment decisions, financing decisions and dividend policy on the value of companies listed on the Indonesia Stock Exchange.

Population in this research are manufacturing companies listed on the Stock Exchange from 2010-2013. After the selection of samples by purposive sampling method obtained a sample of 44 observations for four years. The research data was obtained from the published annual reports and stock price data downloaded from www.finance.yahoo.com. The analysis tool used is multiple linear regression and hypothesis testing is done by using the coefficient of determination, F test and t test. The data were processed using SPSS.

From the test results can be seen that the variable dividend policy does not affect the value of the company, while variable investment decisions and funding decisions, significantly influence the value of the company. Adjusted $R^{2}$ values obtained of 0.250 or $25 \%$. This shows a $25 \%$ coefficient value of the company was affected by investment decisions, financing decisions and dividend policy, while the other $75 \%$, explained by other variables outside the model performed in this study
\end{abstract}

Keywords: Investment Decisions, Decisions Financing, Dividend Policy and Corporate Values.

\section{PENDAHULUAN}

Perkembangan perekonomian di masa sekarang ini mempengaruhi laju pertumbuhan ekonomi secara makro di Indonesia.Peranan pemerintah dalam usaha untuk mencapai pertumbuhan perekonomian yang selaras dan seimbang dimana terdapat struktur ekonomi yang menitikberatkan pada sektor perdagangan dan pelayanan jasa keuangan yang di dukung oleh sektor pertanian.Ini tentunya membuka kesempatan yang luas bagi dunia usaha untuk mengembangkan diri, seiring dengan tuntutan dan keinginan masyarakat.Kemajuan pembangunan dibutuhkan peran serta semua pihak dalam pembangunan.Tuntutan dan tantangan tersebut juga diharapkan pada setiap industri jasa keuangan dan perdagangan.Faktor lain yang tidak kalah pentingnnya adalah peran investor dalam memajukan perekonomian di Indonesia (Ansori dan Denica, 2010).

Menurut pendapat Arieska dan Gunawan (2011), tujuan utama perusahaan adalah meningkatkan nilai perusahaan melalui peningkatan kemakmuran politik para pemegang saham.Pemegang saham, kreditor dan manajer adalah pihak-pihak yang memiliki perbedaan kepentingan dan perspektif berkenaan dengan perusahaan. Pemegang saham akan cenderung memaksimalkan nilai saham dan memaksa manajer untuk bertindak sesuai dengan kepentingan mereka melalui pengawasan yang mereka lakukan. Kreditor di sisi lain cenderung akan berusaha melindungi dana yang sudah mereka investasikan dalam perusahaan dengan jaminan dan kebijakan pengawasan yang ketat pula. Manajer juga memiliki dorongan untuk mengejar kepentingan pribadi mereka.Bahkan tidak tertutup kemungkinan para manajer melakukan investasi walaupun investasi tersebut tidak dapat memaksimalkan nilai pemegang saham. 
Perubahan-perubahan nilai perusahaan pada saat pembagian deviden diumumkan dapat dilihat pada perusahaan manufaktur yang terdaftar di BEI pada periode 2010-2013. Untuk melihat perubahan nilai perusahaan yang terjadi di periode pengamatan 2011 maka menggunakan perbandingan pembagian deviden tahun 2010 dengan pembagian deviden yang di peroleh pada tahun 2011. PT Holcim Indonesia Tbk (SMCB) pada tahun 2011 membukukan nilai perusahaan sebesar 2.21 lebih rendah dari tahun 2010 sebesar 2.53 akan tetapi hal ini diikuti oleh perubahan pembagian deviden yang positif. Pembagian deviden justru meningkat dari 20.78 menjadi 22.52. Hal yang senada juga terjadi pada PT United Tractors Tbk (UNTR), perusahaan ini berhasil mencetak nilai perusahaan pada tahun 2010 sebesar 4.9 kemudian menurun pada tahun berikutnya menjadi 3.57 dan sebaliknya pembagian deviden meningkat dari 36.45 ke 40.4.

PT Semen Indonesia (dh/ Semen Gresik (Persero) ) Tbk (SMGR) pada tahun 2011 membukukan nilai perusahaan sebesar 4.65 kondisi ini meningkat pada tahun 2012 yang sebesar 5.18 namun sebaliknya pembagian deviden justru menurun dari $49.62 \mathrm{ke} 44.29$. Hal yang sama juga terjadi pada PT Supreme Cable Manufacturing \& Commerce (Sucaco) Tbk (SCCO) yang membukukan nilai perusahaan pada tahun 2011 sebesar 1.24 dan meningkat pada tahun 2012 menjadi 1.27 tetapi pembagian deviden menurun dari 31.82 ke 30.28 .

Fenomena di atas menunjukkan bahwa tidak semua kenaikan nilai perusahaan akan diikuti dengan pembagian deviden yang positif dan tidak semua penurunan nilai perusahaan akan diiku ti oleh pembagian deviden yang negatif. Hal ini mengindikasikan bahwa dalam menilai perusahaan memang membutuhkan informasi tentang kondisi keuangan perusahaan tetapi tidak hanya informasi tentan pembagian deviden saja tetapi juga membutuhkan banyak informasi lainnya.

Fama dan French (1998) dalam Wijaya (2010), berpendapat bahwa optimalisasi nilai perusahaan dapat dicapai melalui pelaksanaan fungsi manajemen keuangan, dimana satu keputusan keuangan yang diambil akan mempengaruhi keputusan keuangan lainnya dan berdampak pada nilai perusahaan. Brigham dan Houston (2006) dalam Wati dan Darmayanti (2013) mengemukakan bahwa nilai perusahaan dipengaruhi oleh tindakan-tindakan manajerial yaitu keputusan investasi, keputusan pendanaan dan kebijakan dividen.

Melakukan kegiatan investasi merupakan keputusan tersulit bagi manajemen perusahaan karena akan mempengaruhi nilai perusahaan (Vranakis and Prodromos, 2012 dalam Gayatri dan Mustanda, 2014). Tujuan dilakukannya keputusan investasi adalah mendapat laba yang besar dengan risiko yang dapat dikelola dengan harapan dapat mengoptimalkan nilai perusahaan (Afzal dan Rohman, 2012).Dalam penelitian yang dilakukan Gayatri dan Mustanda (2014), Prasetyo et.al.(2013) menunjukkan bahwa keputusan investasi berpengaruh positif terhadap nilai perusahaan.Hal ini berbeda dengan hasil penelitian Nurfaridah (2011) yang menemukan bahwa variabel investasi memiliki pengaruh negatif terhadap nilai perusahaan.

Kebijakan lain yang berkenaan dengan nilai perusahaan adalah Keputusan pendanaan, keputusan pendanaan didefinisikan sebagai keputusan yang menyangkut komposisi pendanaan yang dipilih oleh perusahaan (Hasnawati, 2005 dalam Afzal dan Rohman, 2012). Menurut Brigham dan Houston (2001) dalam Wijaya dan Wibawa (2010), peningkatan hutang diartikan oleh pihak luar tentang kemampuan perusahaan untuk membayar kewajiban di masa yang akan datang atau adanya resiko bisnis yang rendah, hal tersebut akan direspon secara positif oleh pasar.

Dalam penelitian yang dilakukan Ansori dan Denica (2010) menunjukkan bahwa keputusan pendanaan berpengaruh positif dan signifikan terhadap nilai perusahaan.Artinya apabila keputusan investasi meningkat maka nilai perusahaan akan meningkat.Hal ini berbeda dengan hasil penelitian Mardiyati et.al. (2012) yang menemukan bahwa kebijakan hutang memiliki pengaruh positif tetapi tidak signifikan terhadap nilai perusahaan.

Satu lagi kebijakan yang harus diperhatikan dalam mengoptimalkan nilaiperusahaan adalah kebijakan dividen dimana para investor memiliki tujuan utamauntuk meningkatkan kesejahteraan dengan mengharapkan pengembalian dalambentuk dividen maupun capital gain, sedangkan perusahaan mengharapkanpertumbuhan secara terus menerus untuk mempertahankan 
kelangsunganhidupnya sekaligus memberikan kesejahteraan kepada para pemegang sahamnya,sehingga kebijakan dividen penting untuk memenuhi harapan pemegang saham terhadap dividen dengan tidak menghambat pertumbuhan perusahaan di sisi lain (Afzal dan Rohman 2012). Kebijakan dividen akan berpengaruh positif terhadap nilai saham, melalui penciptaan keseimbangan di antara dividen saat ini dan laba ditahan sehingga mampu memaksimalkan nilai saham (Amri, 2008).

Menurut Wijaya dan Wibawa (2010) menunjukkan bahwa kebijakan dividen berpengaruh positif dan signifikan terhadap nilai perusahaan.Berbeda dengan hasil penelitian dilakukan oleh Gayatri dan Mustanda (2014), Afzal dan Rohman (2012) yang menemukan bahwa kebijakan dividen berpengaruh negatif dan tidak signifikan terhadap nilai perusahaan.

Berdasarkan hasil penelitian terdahulu tersebut peneliti memilih melakukan penelitian pada periode yang berbeda dengan alasan diharapkan dapat menghasilkan perilaku keputusan yang berbeda, sehingga perlu dilakukan penelitian kembali untuk mengetahui sejauh mana keputusan keuangan mempengaruhi nilai perusahaan manufaktur yang terdaftar di BEI periode 2010-2013.Meskipun penelitian ini sudah banyak dilakukan, namun topik nilai perusahaan ini dipandang masih relevan untuk diteliti kembali karena keberagaman dan ketidakkonsistenan hasil dari pengaruh keputusan investasi, keputusan pendanaan dan kebijakan dividen terhadap nilai perusahaan yang diperoleh dari penelitian sebelumnya.Data yang digunakan pada penelitian ini menggunakan data tahun 2010, 2011, 2012, dan 2013. Objek penelitian yang digunakan adalah perusahaan manufaktur yang terdaftar di Bursa Efek Indonesia (BEI) pada periode 2010 sampai dengan 2013. Alasan memilih perusahaan-perusahaan publik yang masuk dalam kategori perusahaan manufaktur ini didasarkan pada pertimbangan akan homogenitas dalam aktivitas produksinya dan kelompok industri ini yang relatif besar jika dibandingkan dengan kelompok industri yang lain di Bursa Efek Indonesia, sehingga mendominasi bursa dan mempunyai kontribusi yang besar terhadap perkembangan bursa.

Berdasarkan uraian tersebut diatas, penulis tertarik melakukan penelitian dengan judul penelitian "Pengaruh Keputusan Investasi, Keputusan Pendanaan, dan Kebijakan Dividen Terhadap Nilai Perusahaan Pada Perusahaan Manufaktur yang Terdaftar Di Bursa Efek Indonesia Periode 2010 - 2013”.

\section{TELAAH PUSTAKA}

\section{Teori Struktur Modal}

Teori pertukaran (Trade-off Theory) adalah Teori struktur modal yang menyatakan bahwa perusahaan menukar manfaat pajak dari pendanaan utang dengan masalah yang ditimbulkan oleh potensi kebangkrutan (Brigham dan Houston, 2011).Pecking Order Theory pertama kali dikemukakan oleh Myers dan Majluf(1984) dalam Wijaya (2010), menyatakan bahwa perusahaan melakukan keputusan pendanaan secarahierarki dari pendanaan internal dan eksternal, dari pendanaan yang bersumber padaprofit, hutang, sampai dengan saham (dimulai dari sumber dana dengan biaya yangtermurah).

\section{Teori Kebijakan Dividen}

a. Dividen Adalah Tidak Relevan

Menurut Modigliani-Miller (MM), nilai suatu perusahaan tidak ditentukan besar kecilnya DPR, tapi ditentukan oleh laba bersih sebelum pajak (EBIT) dan kelas resiko perusahaan. Jadi menurut MM, dividen adalah tidak relevan.

b. Teori Bird in The Hand

Gordon-Lintner menyatakan bahwa biaya modal sendiri perusahaan akan naik jika DPR rendah karena investor lebih suka menerima dividen daripada capital gains. Menurut mereka, investor memandang dividen yield lebih pasti daripada capital gains yield.

c. Teori Tax Differential

Apabila dividen cenderung dikenakan pajak yang lebih tinggi daripadacapital gain, maka investor akan meminta tingkat keuntungan yang lebihtinggi untuk saham dengan dividend yield yang tinggi, sehingga perusahaanlebih baik menentukan dividend payout 
ratio yang rendah atau bahkan tidakmembagikan dividen sama sekali untuk meminimumkan biaya modal danmemaksimumkan nilai perusahaan.

\section{Teori Keagenan}

Agency problem biasanyaterjadi antara manajer dan pemegang saham atau antara debtholders dan stockholders.Agency problem potensial terjadi dalam perusahaan yang manajernya memilkikurang dari seratus persen saham perusahaan.Pemilik sekaligus manajer padaperusahaan perseorangan selalu bertindak memaksimumkan kemakmuran mereka danmeminimumkan pengeluaran yang tidak diperlukan, tetapi apabila pemilikperusahaan menjual sebagian saham kepada investor lain, maka muncul agency problem.

\section{Keputusan Investasi}

Keputusan investasi adalah keputusan keuangan (financial decision) tentang aktiva mana yangharus dibeli perusahaan.Aktiva tersebut berupa aktiva riil (real assets).Aktiva riildapat berupa aktiva nyata (tangible assets) seperti mesin, gedung, perlengkapan, atauberupa aktiva tidak nyata (intangible assets) seperti paten, hak cipta, dan merk.

\section{Keputusan Pendanaan}

Keputusan pendanaan adalah keputusan keuangan tentang darimana danauntuk membeli aktiva tersebut berasal. Ada dua macam dana atau modal meliputimodal asing seperti hutang bank dan obligasi, serta modal sendiri seperti laba ditahandan saham. Keputusan pendanaan dapat dibagi menjadi dua meliputi keputusanpendanaan jangka pendek dan keputusan pendanaan jangka panjang. Keputusanpendanaan jangka pendek meliputi hutang jangka pendek seperti hutang wesel danhutang dagang. Sedangkan keputusan pendanaan jangka panjang akan membawadampak pada struktur modal (capital structure) perusahaan.

\section{Kebijakan Dividen}

Kebijakan dividen adalah keputusan tentang seberapa banyak laba saat ini akan dibayarkan sebagai dividen atau ditahan untuk diinvestasikan kembali dalam perusahaan. Dengan demikian adanya dividen yang optimal merupakan suatu kebijakan dividen yang menciptakan keseimbangan antara dividen saat ini dan pertumbuhan di masa yang akan datang sehingga dapatmemaksimalkan harga perusahaan.

\section{Nilai Perusahaan}

Nilai perusahaan atau juga disebut dengan nilai pasar perusahaanmerupakan harga yang bersedia dibayar oleh calon pembeli apabila perusahaantersebut dijual.Fakta menunjukkan bahwa nilai kekayaan yang ditunjukkan padaneraca tidak memiliki hubungan dengan nilai pasar dari perusahaan.Hal inidisebabkan karena perusahaan memiliki kekayaan yang tidak bisa dilaporkandalam neraca seperti manajemen yang baik, reputasi yang baik, dan prospek yangcerah (Erlangga dan Suryandari, 2009 dalam Afzal dan Rohman, 2012).

\section{Hubungan Logis Antar Variabel dan Perumusan Hipotesis Pengaruh Keputusan Investasi terhadap Nilai Perusahaan}

Secara umum, tujuan orang atau investor melakukan investasi adalah untuk mendapatkan keuntungan di masa yang akan datang. Secara khusus, menurut Tandelilin (2001) dalam Eviana (2013) ada beberapa alasan mengapa investor melakukan investasi, antara lain adalah: mendapatkan kehidupan yang lebih layak di masa mendatang, mengurangi tekanan inflasi, dorongan untuk menghemat pajak.

Menurut Wahyudi dan Pawestri (2006), nilai perusahaan yang dibentukmelalui indikator nilai pasar saham sangat dipengaruhi oleh peluang-peluanginvestasi.Nilai perusahaan semata-mata ditentukan oleh keputusan investasi.Pernyataan sesuai hasil penelitian Fama dan French (1998) dalam Afzal (2012), yang menemukanbahwa investasi yang dihasilkan dari kebijakan dividend dan leverage memilikiinformasi yang positif tentang perusahaan di masa yang akan datang, 
selanjutnyaberdampak positif terhadap nilai perusahaan.Berdasarkan uraian di atas, dapat ditarik hipotesis sebagai berikut:

\section{H1 : Keputusan investasi berpengaruh terhadap nilai perusahaan.}

\section{Pengaruh Keputusan Pendanaan terhadap Nilai Perusahaan}

Menurut Brigham dan Houston (2001) dalam Prapaska dan Siti (2012), peningkatan hutang diartikan oleh pihak luar tentang kemampuan perusahaan untuk membayar kewajiban di masa yang akan datang atau adanya risiko bisnis yang rendah, hal tersebut akan direspon secara positif oleh pasar. Terdapat dua pandangan mengenai keputusan pendanaan.Pandangan pertama dikenal dengan pandangan tradisional yang menyatakan bahwa struktur modal mempengaruhi nilai perusahaan.Pandangan tradisional diwakili oleh dua teori yaitu Trade off Theory dan Pecking Order Theory.Trade off Theory memperbandingkan manfaat dan biaya atau keseimbangan antara keuntungan dan kerugian atas penggunaan hutang.Pecking Order Theory menetapkan suatu urutan keputusan pendanaan dimana para manajer pertama kali akan memilih untuk menggunakan laba ditahan, hutang dan penerbitan saham sebagai pilihan terakhir (Mamduh, 2004 dalam Prapaska dan Siti, 2012). Pandangan kedua dikemukakan oleh Modigliani dan Miller (1958) dalam Wijaya (2010) yang menyatakan bahwa struktur modal tidak mempengaruhi nilai perusahaan.Berdasarkan uraian di atas, dapat ditarik hipotesis sebagai berikut:

\section{H2 :Keputusan Pendanaan berpengaruh terhadap nilai perusahaan.}

\section{Pengaruh Kebijakan Dividen terhadap Nilai Perusahaan}

Pada dasarnya, laba bersih perusahaan bisa dibagikan kepada pemegangsaham sebagai dividen atau ditahan dalam bentuk laba ditahan untuk membiayaiinvestasi perusahaan.Kebijakan dividen menyangkut keputusan tentangpenggunaan laba yang menjadi hak pemegang saham (Afzal, 2012).Menurut Hatta (2002) dalam Wijaya dan Wibawa (2010), terdapatsejumlah perdebatan mengenai bagaimana kebijakan deviden mempengaruhi nilaiperusahaan.Pendapat pertama menyatakan bahwa kebijakan dividen tidakmempengaruhi nilai perusahaan, yang disebut dengan teori irrelevansi dividen.Pendapat kedua menyatakan bahwa dividen yang tinggi akan meningkatkan nilaiperusahaan, yang disebut dengan Bird in The Hand Theory. Pendapat ketigamenyatakan bahwa semakin tinggi dividend payout ratio suatu perusahaan, makanilai perusahaan tersebut akan semakin rendah.Berdasarkan uraian di atas, dapat ditarik hipotesis sebagai berikut:

\section{H3 : Kebijakan Dividen berpengaruh terhadap nilai perusahaan.}

\section{Kerangka Pemikiran}

Kerangka pemikiran yang menggambarkan hubungan antara keputusan investasi, keputusan pendanaan, dan kebijakan dividen dengan nilai perusahaan adalah sebagai berikut :

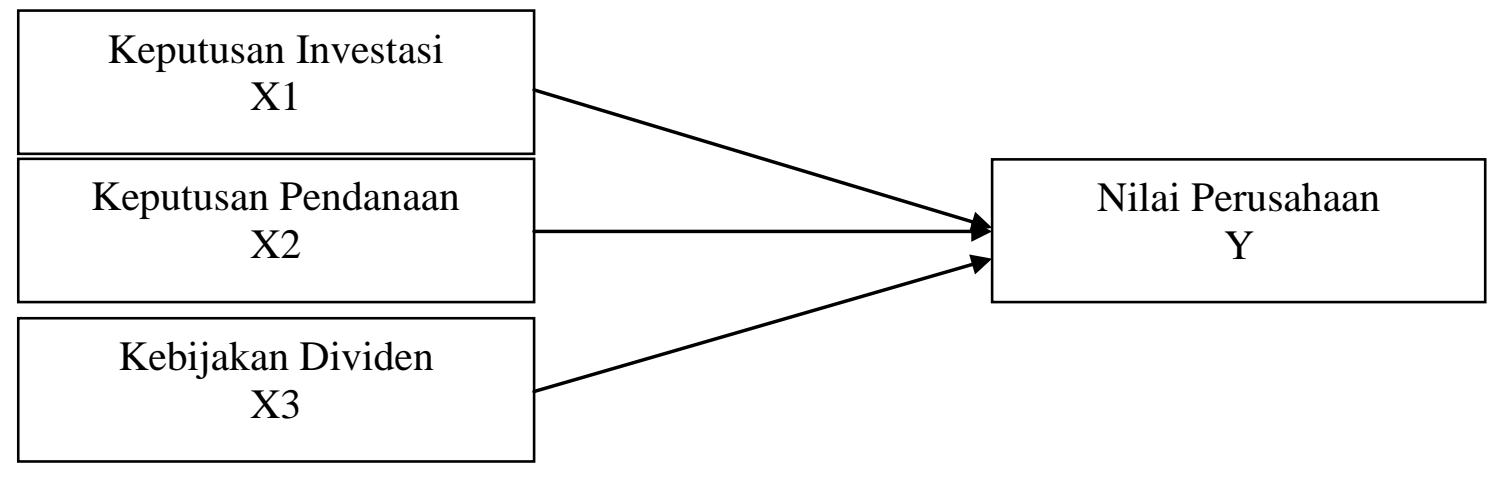




\section{METODE PENELITIAN}

Dalam penelitian ini menggunakan dua jenis variabel yaitu variabel terikat/ dependen (diberi simbol y) dan variabel bebas / independen (diberi simbol x). Identifikasi masing-masing variabel yang digunakan dalam penelitian ini sebagai berikut :

\section{a. Variabel Terikat}

Variabel terikat (dependen) adalah variabel yang memberikan reaksi/respon jika dihubungan dengan variabel yang lain. Atau dengan kata lain, variabel yang nilainya dipengaruhi oleh variabel lain. Variabel terikat dalam penelitian ini adalah Nilai Perusahaan.

\section{b. Variabel Bebas}

Variabel bebas (independen) adalah variabel stimulus atau variabel yang mempengaruhi variabel lain. Dalam penelitian ini variabel bebas yang digunakan adalah Keputusan Investasi, Keputusan Pendanaan, dan Kebijakan Dividen.

\section{Variabel Dependen (Y): Nilai Perusahaan}

Nilai perusahaan dalam penelitian ini didefinisikan sebagai nilai pasar karena nilai perusahaan dapat memberikan kemakmuran pemegang saham secara maksimum apabila harga saham perusahaan meningkat (Hasnawati, 2005 dalam Wijaya, 2010). Nilaiperusahaan dalam penelitian ini dikonfirmasikan melalui Price Book Value (PBV).PBV digunakan dalam penelitian ini karenamenggambarkan seberapa besar pasar menghargai nilai buku saham suatuperusahaan. Semakin tinggi PBV, maka semakin baik karena berarti pasar percayaakan prospek perusahaan. Sebaliknya, semakin rendah PBV, maka semakin burukkarena berarti pasar tidak percaya akan prospek perusahaan.

$$
\text { Price Book Value }(\mathrm{PBV})=\frac{\text { Harga Saham }}{\mathrm{BV}}
$$

\section{Variabel Independen (X1): Keputusan Investasi}

Keputusan investasi yang didefinisikan sebagai kombinasi antaraaktiva yang dimiliki (assets in place) dan pilihan investasi di masa yang akan datang dengan net present value positif (Myers, 1977 dalam Wijaya danWibawa, 2010). Keputusan investasi dalam penelitian ini diproksikan denganPER (Price Earning Ratio), dimana PER menunjukkan perbandingan antaraclosing price dengan laba per lembar saham (earning per share). PERdirumuskan dengan : (Wijaya dan Wibawa, 2010)

$$
\text { Prince Earning Ratio }(\mathrm{PER})=\frac{\text { Harga Saham }}{\text { EPS }}
$$

\section{Variabel Independen (X2): Keputusan Pendanaan}

Keputusan pendanaan dalam penelitian ini dikonfirmasikan melalui Debt to Equity Ratio (DER).DER merupakan perbandingan total hutang yang dimiliki perusahaan dengan total ekuitas perusahaan. Rumus sebagai berikut : (Gayatri dan Mustanda, 2014)

$$
\text { Debt to Equity Ratio }(\mathrm{DER})=\frac{\text { Total Hutang }}{\text { Total Ekuitas }}
$$

\section{Variabel Independen (X3): Kebijakan Dividen}

Menurut Ansori dan Denica (2010) kebijakan dividen adalah kebijakan perusahaan berhubungan dengan penentuan presentase laba bersih perusahaan yang dibagikan sebagai dividen kepada pemegang saham.Sebagai variabel independen, kebijakan dividen diproksikan melalui Dividend Payout Rasio (DPR). Rumus DPR adalah sebagai berikut : (Mardiyati, 2012) 


$$
\text { Dividend Payout Rasio }(\mathrm{DPR})=\frac{\text { Dividen per lembar saham }}{\text { Laba per lembar saham }}
$$

\section{Populasi dan Sampel}

Populasi dalam penelitian ini adalah perusahaan manufaktur yang terdaftardi Bursa Efek Indonesia (BEI) pada periode 2010-2013. Sampel penelitian ini diperoleh dengan metode purposivesampling.Adapun kriteria yang digunakan untuk memilih sampel pada penelitian ini adalahsebagai berikut :

1) Perusahaan yang termasuk dalam kelompok industri manufaktur yangterdaftar di BEI dan mempublikasikan laporan keuangan berturut-turut dari tahun 2010-2013.

2) Perusahaan manufaktur yang memiliki dividend payout ratioberturut-turut dari tahun 20102013.

3) Perusahaan yang memiliki laporan keuangan secara lengkap selama tahun 2010-2013, baik secara fisik maupun melalui website.

\section{Jenis dan Sumber Data}

Jenis data yang digunakan dalam penelitian ini adalah data sekunder. Data sekunder adalah sumber data penelitian yang diperoleh secara tidak langsung melalui perantara baik yang dipublikasikan dan tidak dipublikasikan. Data yang digunakan adalah data laporan keuangan meliputi : Harga penutupan saham, Laba per saham, Total hutang, Total ekuitas, Dividen per saham, Nilai buku per lembar saham.Data tersebut diperoleh dari publikasi laporan keuangan yang diterbitkan oleh Bursa Efek Indonesia (BEI), IndonesianCapital Market Directory (ICMD).Sumber data yang digunakan dalam penelitian ini diperoleh dari Indonesia Stock Exchange (IDX) Bursa Efek Indonesia Kantor Perwakilan Semarang dan Perpustakaan Pusat Informasi Pasar Modal (PIPM) Semarang.

\section{Metode Pengumpulan Data}

Metode pengumpulan data yang digunakan dalam penelitian ini adalah metode dokumentasi, yaitu pengumpulan data yang dilakukan dengan cara mempelajari catatan-catatan atau dokumen-dokumen perusahaan sesuai dengan data yang diperlukan. Untuk penelitian ini, pengumpulan data diperoleh dari data yang dipublikasikan Indonesian Capital Market Directory(ICMD) tahun 2011, 2012, 2013, dan 2014 untuk mendapatkan data variabel keputusan investasi, keputusan pendanaan, dan kebijakan dividen yang terkait dalam penelitian ini.

\section{Metode Analisis}

Metode analisis yang digunakan adalah analisis regresi berganda, Untuk mengetahui apakah model regresi benar-benar menunjukkan hubungan yang signifikan dan representatif maka model tersebut harus memenuhi uji asumsi klasik. Model matematis dalam penelitian ini dapat di rumuskan sebagai berikut:

$\mathrm{PBV}=\alpha+\beta 1 \mathrm{PER}+\beta 2 \mathrm{DER}+\beta 3 \mathrm{DPR}+\mathrm{e}$

Keterangan :

$\mathrm{PBV}=$ Price Book Value

$\alpha=$ Konstanta

PER = Price Earning Ratio

$\mathrm{DER}=$ Debt to Equity Ratio

$\mathrm{DPR}=$ Dividend Payout Ratio

$\beta 1, \beta 2, \beta 3=$ Koefisien Regresi

$\mathrm{e}=$ Kesalahan Pengganggu 
HASIL PENELITIAN DAN PEMBAHASAN

Adapun proses seleksi sampel yaitu sebagai berikut:

Tabel 1-Proses Seleksi Sampel dengan Kriteria

\begin{tabular}{|c|l|c|}
\hline No & \multicolumn{1}{|c|}{ Kriteria Sampel } & $\begin{array}{c}\text { Memenuhi } \\
\text { Kriteria }\end{array}$ \\
\hline 1 & $\begin{array}{l}\text { Total Perusahaan Manufaktur Yang Terdaftar di BEI tahun } \\
2010 \text {-2013 }\end{array}$ & 105 \\
\hline 2 & $\begin{array}{l}\text { Perusahaan manufaktur yang tidak memiliki dividend payout } \\
\text { ratio berturut-turut dari tahun 2010-2013. }\end{array}$ & 14 \\
\hline 3 & $\begin{array}{l}\text { Perusahaan manufaktur yang memiliki dividend payout ratio } \\
\text { berturut-turut dari tahun 2010-2013. }\end{array}$ & 14 \\
\hline 4 & $\begin{array}{l}\text { Perusahaan yang tidak memiliki laporan keuangan secara } \\
\text { lengkap selama tahun 2010-2013, baik secara fisik maupun } \\
\text { melalui website. }\end{array}$ & 14 \\
\hline 5 & $\begin{array}{l}\text { Perusahaan yang memiliki laporan keuangan secara lengkap } \\
\text { selama tahun 2010-2013, baik secara fisik maupun melalui } \\
\text { website. }\end{array}$ & $\mathbf{1 4}$ \\
\hline 6 & Jumlah perusahaan yang menjadi obyekpenelitian & \\
\hline
\end{tabular}

Sumber: Data sekunder yang diolah, 2015

Dari 14 perusahaan yang menjadi obyek dalam penelitian ini, ada tiga perusahaan yang memiliki data yang ekstrim, sehingga dikeluarkan dari sampel. Akhirnya jumlah sampel perusahaan yang digunakan hanya tinggal 11 dengan periode empat tahun, sehingga jumlah data menjadi 44.

\section{Hasil Analisis Deskritif}

Deskriptif statistik memberikan gambaran umum atau deskripsi dari data perusahaan sampel, dapat dilihat pada tabel berikut:

Tabel 2 - Descriptive Statistics

\begin{tabular}{|l|r|r|r|r|r|}
\hline & $\mathrm{N}$ & $\begin{array}{c}\text { Minimu } \\
\mathrm{m}\end{array}$ & $\begin{array}{c}\text { Maximu } \\
\mathrm{m}\end{array}$ & Mean & \multicolumn{1}{c|}{$\begin{array}{c}\text { Std. } \\
\text { Deviation }\end{array}$} \\
\hline PBV & 44 & .56 & 8.27 & 2.9736 & 1.81350 \\
PER & 44 & 2.37 & 63.86 & 16.3855 & 12.15578 \\
DER & 44 & .10 & 1.94 & .7675 & .50859 \\
DPR & 44 & .07 & 84.17 & 25.6057 & 20.87421 \\
Valid N & 44 & & & & \\
(listwise) & & & & & \\
\hline
\end{tabular}

Sumber : data sekunder yang diolah, SPSS

\section{Hasil Pengujian Asumsi Klasik:}

Sebelum data dianalisis lebih lanjut, maka data harus memenuhi beberapa asumsi dalam pengambilan keputusan:

a. Uji Normalitas

Pengujian normalitas dapat dilakukan dengan menggunakan grafik probability plot of residual.Hasil pengujian telah menunjukkan residual error telah mendekati garis diagonal (garis normal), tersebar di sekitar garis lurus, sehingga asumsi normalitas telah terpenuhi. Uji normalitas ini juga diperkuat dengan hasil uji Kolmogorov-Smirnov yang menunjukkan nilai K- 
S sebesar 0.493 dengan signifikansi 0,968 yang berarti bahwa data telah memenuhi asumsi normalitas.

Tabel 3 -One-Sample Kolmogorov-Smirnov Test

\begin{tabular}{|ll|r|}
\hline & & $\begin{array}{c}\text { Unstandardize } \\
\text { d Residual }\end{array}$ \\
\hline $\mathrm{N}$ & Mean & 44 \\
Normal Parameters & a,b & Std. \\
& Deviation & 1.51445309 \\
Most Extreme & Absolute & .111 \\
Differences & Positive & .111 \\
Kolmogorov-Smirnov Z &. .058 \\
Asymp. Sig. (2-tailed) & .738 \\
\hline
\end{tabular}

a. Test distribution is Normal.

b. Calculated from data.

Sumber : data sekunder yang diolah, SPSS

Gambar 1 - Hasil Uji Normalitas

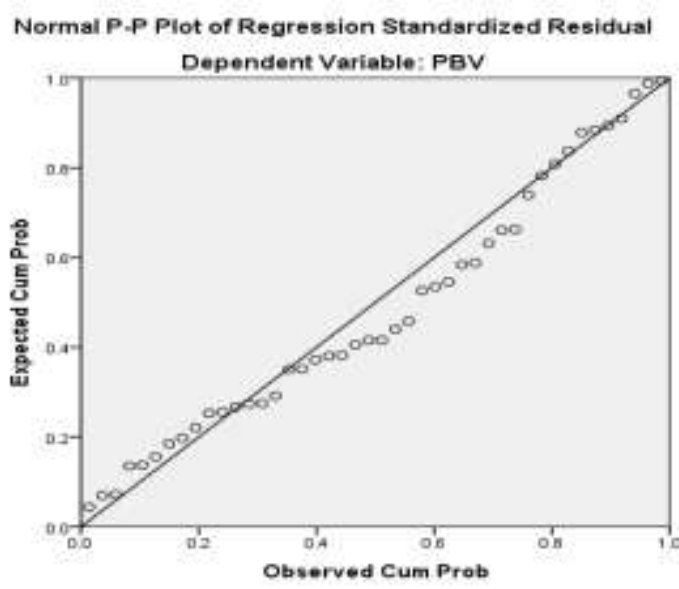

b. Uji Multikolinearitas

Untuk mendeteksi ada tidaknya multikolinieritas pada data, dapat diperiksa dengan menggunakan Faktor Inflasi Varian (VIF). Nilai cutoff yang digunakan untuk menunjukkan terjadi multikolinearitas adalah nilai tolerance $>0,1$ dan nilai $\mathrm{VIF}<10$. Berdasarkan hasil pengujian regresi, diperoleh nilai VIF untuk masing-masing variabel independen sebagai berikut:

Tabel 4 - Hasil Pengujian Multikolinearitas dengan VIF Coefficients $^{\mathbf{a}}$

\begin{tabular}{|c|c|c|c|}
\hline \multirow{2}{*}{\multicolumn{2}{|c|}{ Model }} & \multicolumn{2}{|c|}{ Collinearity Statistics } \\
\hline & & Tolerance & VIF \\
\hline \multirow{3}{*}{1} & PER & .880 & 1.137 \\
\hline & DER & .761 & 1.315 \\
\hline & DPR & .712 & 1.404 \\
\hline
\end{tabular}

a. Dependent Variable: PBV

Sumber : data sekunder yang diolah, SPSS 
c. Uji Heteroskedastisitas

Pengujian heteroskedastisitas dalam penelitian ini menggunakan Scatterplot dan Uji Glejser.Pada gambar ini data terlihat menyebar.

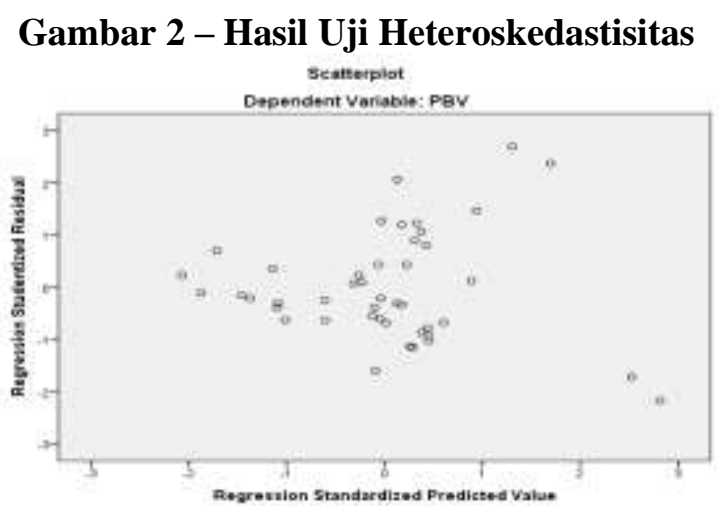

Hasil uji park juga menunjukkan bahwa semua variabel telah memiliki nilai signifikansi diatas 5\%. Berdasar kedua pengujian tersebut, maka data terpilih dalam penelitian ini telah memenuhi syarat bebas heteroskedastisitas.

Tabel5 - Hasil Uji Glejser

Coefficients $^{\mathrm{a}}$

\begin{tabular}{|c|c|c|c|c|c|c|}
\hline \multirow{2}{*}{\multicolumn{2}{|c|}{ Model }} & \multicolumn{2}{|c|}{$\begin{array}{l}\text { Unstandardized } \\
\text { Coefficients }\end{array}$} & $\begin{array}{l}\text { Standardized } \\
\text { Coefficients }\end{array}$ & \multirow[t]{2}{*}{$\mathrm{T}$} & \multirow[t]{2}{*}{ Sig. } \\
\hline & & B & Std. Error & Beta & & \\
\hline \multirow{4}{*}{1} & (Constant) & .999 & .388 & & 2.576 & .021 \\
\hline & PER & .019 & .012 & .327 & 1.547 & .143 \\
\hline & DER & -.395 & .210 & -.438 & -1.883 & .079 \\
\hline & DPR & .002 & .005 & .099 & .428 & .675 \\
\hline
\end{tabular}

a. Dependent Variable: ABSUt

Sumber : data sekunder yang diolah, SPSS

d. Uji Autokorelasi

Untuk mengetahui ada tidaknya autokorelasi harus dilihat nilai uji run test.

Tabel 6 - Hasil Run test

Runs Test

\begin{tabular}{|l|r|}
\hline & $\begin{array}{c}\text { Unstandardize } \\
\text { d Residual }\end{array}$ \\
\hline Test Value $^{\mathrm{a}}$ & -.33449 \\
Cases < Test Value & 22 \\
Cases > = Test Value & 22 \\
Total Cases & 44 \\
Number of Runs & 23 \\
Z & .000 \\
Asymp. Sig. (2- & 1.000 \\
tailed) & \\
\hline
\end{tabular}

a. Median

Sumber : data sekunder yang diolah, SPSS

Dari tabel diatas menunjukkan bahwa nilai test adalah $-0,33449$ dengan probabilitas 1.000 signifkan pada 0,05 yang berarti hipotesis nol diterima, sehingga dapat disimpulkan 
bahwa residual random atau tidak terjadi autokorelasi antar nilai residual. Dengan dipenuhinya keempat asumsi klasik di atas, maka uji selanjutnya bisa dilakukan.

\section{Persamaan Regresi Linier Berganda}

Adapun hasil ringkasan dari uji regresi dapat dilihat sebagai berikut ini :

\begin{tabular}{|l|r|r|r|}
\hline \multicolumn{1}{|c|}{ Model } & Coefficients & t & Sig \\
\hline (Constant) & 3,463 & 3,988 &, 000 \\
\hline X1_PER &, 054 & 2,580 &, 014 \\
\hline X2_DER & $-1,370$ & $-2,538$ &, 015 \\
\hline X3_DPR &,- 013 &,- 936 &, 355 \\
\hline $\mathbf{F}$ & $5,786$ (P-value $=0,002)$ & & \\
\hline $\mathbf{R}^{2}$ & $25 \%$ & & \\
\hline $\mathbf{N}$ & 44 & & \\
\hline
\end{tabular}

Berdasarkan tabel di atas model regresi yang terjadi adalah :

$$
\mathrm{Y}=3.463+0.054 \mathrm{PER}-1.370 \mathrm{DER}-0.013 \mathrm{DPR}+\mathrm{e}
$$

a) Jika PER mempunyai koefisien regresi sebesar 0.054 (bertanda positif) maka berarti bahwa kenaikan PER akan berpengaruh positif terhadap PBV. Artinya, semakin besar PER maka semakin besar pula PBV.

b) Jika DER mempunyai koefisien regresi sebesar - 1.370 (bertanda negatif) maka berarti bahwa kenaikan DER akan berpengaruh negatif terhadap PBV. Artinya, semakin besar DER maka semakin kecil PBV.

c) Jika DPR mempunyai koefisien regresi sebesar - 0.013 (bertanda negatif) maka berarti bahwa kenaikan DPR akan berpengaruh negatif terhadap PBV. Artinya, semakin besar DPR maka semakin kecil PBV.

\section{Hasil Uji F}

Dari hasil perhitungan didapat nilai $\mathrm{F}$ hitung sebesar 5,786 dengan tingkat signifikansi 0,002 jauh lebih kecil dari 0,05, dengan demikian disimpulkan bahwa model fit sehingga dapat digunakan untuk memprediksi Nilai Perusahaan (PBV).

\section{Koefisien Determinasi $\left(\mathbf{R}^{2}\right)$}

Koefisien Determinasi $\left(\mathrm{R}^{2}\right)$ digunakan untuk mengetahui prosentase perubahan variabel tidak bebas (Y) yang disebabkan oleh variabel bebas (X). nilai Adjusted R Square sebesar 0,250 yang berarti variabilitas variabel dependen yaitu nilai perusahaan yang dapat dijelaskan oleh variabel independen yaitu keputusan investasi, keputusan pendanaan, dan kebijakan dividen adalah sebesar 25 persen, sedangkan sisanya sebesar 75 persen dijelaskan oleh variabel-variabel lain.

\section{Hasil pengujian hipotesis}

\section{1) Pengujian hipotesis pertama $\left(\mathrm{H}_{1}\right)$}

Hipotesis pertama menyatakan bahwa keputusan investasi berpengaruh terhadap nilai perusahaan.Hasil pengujian menunjukkan tingkat signifikansi 0.014 dengan nilai signifikan $\mathrm{t}$ yang lebih kecil dari 5 persen.Sedangkan nilai $\mathrm{t}_{\text {hitung }}$ sebesar 2.580 dan $\mathrm{t}_{\text {tabel }}$ sebesar 2.021 maka $t_{\text {hitung }}(2.580)>t_{\text {tabel }}(2.021)$. Berdasarkan hal tersebut dapat disimpulkan bahwa variabel keputusan investasi berpengaruh signifikan terhadap nilai perusahaan atau dengan kata lain $\mathbf{H}_{1}$ diterima. 
2) Pengujian hipotesis kedua $\left(\mathrm{H}_{2}\right)$

Hipotesis kedua menyatakan bahwa keputusan pendanaan berpengaruh terhadap nilai perusahaan.Hasil pengujian menunjukkan tingkat signifikansi 0.015 dengan nilai signifikan $\mathrm{t}$ yang lebih kecil dari 5 persen.Sedangkan nilai $\mathrm{t}_{\text {hitung }}$ sebesar 2.538 dan $\mathrm{t}_{\text {tabel }}$ sebesar 2.021 maka $t_{\text {hitung }}(2.538)>t_{\text {tabel }}(2.021)$. Berdasarkan hal tersebut dapat disimpulkan bahwa variabel keputusan pendanaan berpengaruh signifikan terhadap nilai perusahaan atau dengan kata lain $\mathbf{H}_{2}$ diterima.

3) Pengujian hipotesis ketiga $\left(\mathrm{H}_{3}\right)$

Hipotesis ketiga menyatakan bahwa kebijakan dividen berpengaruh terhadap nilai perusahaan.Hasil pengujian menunjukkan tingkat signifikansi 0,355 nilai signifikan $\mathrm{t}$ yang lebih besar dari 5 persen.Sedangkan nilai $t_{\text {hitung }}$ sebesar 0.936 dan $t_{\text {tabel }}$ sebesar 2.021 maka $\mathrm{t}_{\text {hitung }}(0.936)<\mathrm{t}_{\text {tabel }}(2.021)$. Berdasarkan hal tersebut dapat disimpulkan bahwa variabel kebijakan dividen tidak berpengaruh signifikan terhadap nilai perusahaan atau dengan kata lain $\mathrm{H}_{3}$ ditolak.

\section{Pembahasan \\ Pengaruh Keputusan Investasi Terhadap Nilai Perusahaan}

Hasil penelitian variabel keputusan investasi terhadap nilai perusahaan menunjukkan bahwa keputusan investasi (PER) berpengaruh secara signifikan positif terhadap nilai perusahaan, sehingga apabila keputusan investasi naik sebesar satu satuan,maka nilai perusahaan juga akan naik. Adanya pengaruh keputusan investasi terhadap nilaiperusahaan menunjukkan bahwa kemampuan perusahaan memaksimumkan investasi dalamupayanya menghasilkan laba sesuai dengan jumlah dana yang terikat (Afzal dan Rohman, 2012).Hal ini dapat terlihat dari uji hipotesispengujian yang menunjukkan tingkat signifikansi 0.014 dengan nilai signifikan $t$ yang lebih kecil dari 5 persen.Sedangkan nilai $t_{\text {hitung }}$ sebesar 2.580 dan $t_{\text {tabel }}$ sebesar 2.021 maka $t_{\text {hitung }}(2.580)>\mathrm{t}_{\text {tabel }}(2.021)$.

Hasil penelitian ini konsisten pula dengan penelitian Wijaya dan wibawa (2010) yang menyatakan bahwa keputusan investasi tersebut adalah keputusan yang mencerminkan kesempatan investasi di masa yang akan datang (investment opportunity), yaitu melalui pengenalan produk baru atau perluasan produk lama, penggantian peralatan atau gedung, penelitian dan pengembangan, serta eksplorasi. Hasil penelitian ini juga mendukung teori sinyal (signaling theory), dimana adanya pengeluaran investasi memberikan sinyal positif mengenai pertumbuhan perusahaan di masa yang akan datang, sehingga dapat meningkatkan harga saham yang digunakan sebagai indikator nilai perusahaan (Wahyudi dan Pawestri, 2006).

Hasil penelitian ini sejalan dengan penelitian Ansori dan Denica (2010), Afzal dan Rohman (2012), serta Prasetyo et.al.(2013), yang menyatakan bahwa keputusan investasi berpengaruh secara positif terhadap nilai perusahaan.Begitu pula dengan penelitian Gayatri dan Mustanda (2014) yang menyebutkan bahwa keputusan investasi berpengaruh terhadap nilai perusahaan.Hasil penelitian ini tidak sejalan dengan pendapat yang dikemukakan oleh NurFaridah (2011) bahwa meningkatnya investasi membuktikan tingginya kebutuhan dana di perusahaan, sedangkan dalam pemenuhan kebutuhan dana perusahaan menggunakan hutang yang mengakibatkan beban bunga meningkat. Dengan kata lain tinggi beban bunga akan mengakibatkan risiko yang tinggi, maka akan mengurangi tingkat kepercayaan investor yang dapat mempengaruhi turunnya harga pasar saham dan berdampak pada penurunan nilai perusahaan.

\section{Pengaruh Keputusan Pendanaan Terhadap Nilai Perusahaan}

Hasil penelitian variabel keputusan pendanaan terhadap nilai perusahaan menunjukkan bahwa keputusan pendanaan (DER) berpengaruh secara signifikan negatif terhadap nilai perusahaan,sehingga apabila keputusan pendanaan naik sebesar satu satuan, maka nilai perusahaan akan turun sebesar satu satuan. Begitu pula sebaliknya, semakin kecil nilai perusahaan maka akan semakin tinggikeputusan pendanaannya. Hal ini dapat terlihat dari uji 
hipotesispengujian yang menunjukkan tingkat signifikansi 0.015 dengan nilai signifikan $\mathrm{t}$ yang lebih kecil dari 5 persen.Sedangkan nilai $t_{\text {hitung }}$ sebesar 2.538 dan $t_{\text {tabel }}$ sebesar 2.021 maka $t_{\text {hitung }}$ $(2.538)>t_{\text {tabel }}$ (2.021).Peningkatan hutang juga dapat diartikan pihak luar tentang kemampuan perusahaan untukmembayar kewajibannya di masa yang akan datang atau risiko bisnis yang rendah, sehinggapenambahan hutang telah memberikan sinyal positif (Brigham dan Houston, 2011).

Hasil penelitian ini sejalan dengan penelitian Ansori dan Denica (2010), Afzal dan Rohman (2012), serta Prasetyo et.al.(2013), yang menyatakan bahwa keputusan pendanaan berpengaruh signifikan terhadap nilai perusahaan.Begitu pula dengan penelitian Gayatri dan Mustanda (2014) yang menyebutkan bahwa keputusan pendanaan berpengaruh terhadap nilai perusahaan.Namun penelitian ini tidak konsisten dengan Modigliani dan Miller (1963) bahwa dengan memasukkan pajak penghasilan perusahaan, maka penggunaanhutang akan meningkatkan nilai perusahaan karena biaya bunga hutang adalah biaya yang mengurangi pembayaran pajak.

\section{Pengaruh Kebijakan Dividen Terhadap Nilai Perusahaan}

Hasil penelitian variabel kebijakan dividen (DPR) terhadap nilai perusahaan menunjukkan bahwa kebijakan dividen (DPR) tidak berpengaruh secara signifikan negatif terhadap nilai perusahaan, sehingga apabila kebijakan dividen naik sebesar satu satuan, maka nilai perusahaan akan turun sebesar satu satuan. Begitu pula sebaliknya, semakin kecil nilai perusahaan maka akan semakin tinggikebijakan dividennya.Hasil pengujian menunjukkan tingkat signifikansi 0,355 nilai signifikan $\mathrm{t}$ yang lebih besar dari 5 persen.Sedangkan nilai $\mathrm{t}_{\text {hitung }}$ sebesar 0.936 dan $\mathrm{t}_{\text {tabel }}$ sebesar 2.021 maka $\mathrm{t}_{\text {hitung }}(0.936)<\mathrm{t}_{\text {tabel }}(2.021)$.

Hal ini sesuai dengan teori yang dikemukakan oleh Miller dan Modligiani yang menyatakan bahwa kebijakan dividen tidak mempengaruhi nilai perusahaan karena menurut mereka rasio pembayaran dividen hanyalah rincian dan tidak mempengaruhi kesejahteraan pemegang saham.Meningkatnya nilai dividen tidak selalu diikuti dengan meningkatnya nilai perusahaan. Karena nilai perusahaan ditentukan hanya oleh kemampuan perusahaan menghasilkan laba dari aset-aset perusahaan atau kebijakan investasinya (Mardiyati et.al.,2012).

Menurut Hatta (2002) dalam Wijaya dan Wibawa (2010), terdapat sejumlah perdebatanmengenai bagaimana kebijakan deviden mempengaruhi nilai perusahaan.Pendapat pertamamenyatakan bahwa kebijakan dividen tidak mempengaruhi nilai perusahaan, yang disebut denganteori irrelevansi dividen. Pendapat kedua menyatakan bahwa dividen yang tinggi akanmeningkatkan nilai perusahaan, yang disebut dengan Bird in The Hand Theory. Pendapat ketigamenyatakan bahwa semakin tinggi dividend payout ratio suatu perusahaan, maka nilai perusahaantersebut akan semakin rendah. Hasil penelitian ini tidak mendukung penelitian Wijaya dan Wibawa(2010), yang membuktikan bahwa kebijakan dividen mempengaruhi nilai perusahaan secarapositif.

\section{PENUTUP}

Hasil penelitian menunjukkan bahwa keputusan investasi dan keputusan pendanaan berpengaruh signifikan terhadap nilai perusahaan.Sedangkan kebijakan dividen tidak berpengaruh signifikan terhadap nilai perusahaan.

\section{Keterbatasan Penelitian}

Adapun keterbatasan dalam penelitian ini antara lain (1) Keterbatasan dalam penelitian ini, yaitu nilai Adjusted $\mathrm{R}^{2}$ yang diperoleh 0,250 atau 25\%. Hal ini menunjukkan $25 \%$ koefisien nilai perusahaan (PBV) dipengaruhi oleh keputusan investasi (PER), keputusan pendanaan (DER), dan kebijakan dividen (DPR), sedangkan sisanya 75\% lainnya, dijelaskan oleh variabel lain di luar model yang dilakukan dalam penelitian ini. Hal ini menunjukkan bahwa kemampuan variabel-variabel independen yang digunakan untuk menjelaskan variabel dependen dalam penelitian ini terbatas. (2) Dalam penelitian ini hanya mengambil sampel dari perusahaan manufaktur, karena perusahaanmanufaktur yang terdekat kaitannya dengan lingkungan dan 
merupakan sektor industri terbesardi bursa efek, sehingga tidak mencerminkan reaksi dari pasar modal secara keseluruhan.

\section{Agenda Penelitian Yang Akan Datang}

Agenda penelitian yang akan datang sebagai berikut, (1) Untuk penelitian selanjutnya disarankan untuk menggunakan faktor eksternal perusahaan sebagai variabel independen yang mempengaruhi nilai perusahaan dengan model penelitian yang memadai agar diperoleh nilai Adjusted $\mathrm{R}^{2}$ yang tinggi. Nilai Adjusted $\mathrm{R}^{2}$ mampu memberikan hampir semua informasi yang dibutuhkan untuk memprediksi variasi variabel dependen. (2) Pada penelitian selanjutnya diharapkan menggunakan sampel dari seluruh perusahaan danmenggunakan tahun pengamatan yang lebih panjang sehingga hasil penelitian dapatmenggambarkan kondisi pasar modal pada seluruh perusahaan.

\section{DAFTAR PUSTAKA}

Afzal, Arie. 2012. "Pengaruh Keputusan Investasi, Keputusan Pendanaan, dan Kebijakan Deviden terhadap Nilai Perusahaan". Skripsi, Fakultas Ekonomi dan Bisnis Universitas Diponegoro Semarang.

Afzal, Arie dan Abdul Rohman. 2012. "Pengaruh Keputusan Investasi, Keputusan Pendanaan, dan Kebijakan Deviden terhadap Nilai Perusahaan". Diponegoro Journal of Accounting, Vol. 1, No. 2, hal. 09.

Ansori, Mokhamat dan Denica H.N. 2010. "Pengaruh Keputusan Investasi, Keputusan Pendanaan, dan Kebijakan Dividen terhadap Nilai Perusahaa". Jurnal Analisis Manajemen, Vol. 4 No. 2.

Amri, Fauzi. 2008. "Analisi Pengaruh Struktur Kepemilikan, Keputusan Investasi,keputusan Pendanaan, dan Kebijakan Dividen terhadap Nilai Perusahaan". Skripsi, Jurusan Manajemen Fakultas Ekonomi dan Ilmu Sosial Universitas Islam Negeri Syarif Hidayatullah Jakarta.

Arieska, Metha dan Barbara Gunawan. 2011. "Pengaruh Aliran Kas Bebas dan Keputusan Pendanaan terhadap Nilai Pemegang Saham dengan Set Keputusan Investasi dan Dividen Sebagai Variabel Moderasi”. Jurnal Akuntansi Keuangan, Vol. 13, No. 1, hal. 13-23.

Atmaja, Lukas Setia. 2008. Teori \& praktik manajemen keuangan. Yogyakarta: Andi.

Ayuni, Ni Luh Prema Sila. 2012. "Analisis Pengaruh Keputusan Investasi, Keputusan Pendanaan, dan Kebijakan Deviden terhadap Nilai Perusahaan”. Skripsi, Sekolah Tinggi Ilmu Ekonomi Bank BPD Jateng Semarang.

Baridwan, Zaki. 2010. Intermediate Accounting. Edisi kedelapan, Yogyakarta: Badan Penerbit Fakultas Ekonomi UGM.

Brigham, Eugene F. dan Joel F. Houston. 2011. Dasar-dasar Manajemen Keuangan. Edisi 11 buku 2, Jakarta: salemba Empat.

Darminto. 2010. "Pengaruh Faktor Eksternal dan Berbagai Keputusan Keuangan terhadap Nilai Perusahaan”. ISSN: 1693-5241, Jurnal Aplikasi Manajemen, Vol. 8, No. 1.

Eviana, Anita. 2013. "Pengaruh Keputusan Investasi, Keputusan Pendanaan, dan Kebijakan Dividen terhadap Nilai Perusahaan”. Skripsi, Fakultas Ekonomi Stikubank Semarang.

Fernandar, Gany Ibrahim. 2012. "Pengaruh Keputusan Investasi, Keputusan Pendanaan, dan Kebijakan Dividen terhadap Nilai Perusahaan". Skripsi, Fakultas Ekonomi dan Bisnis Universitas Diponegoro Semarang.

Gayatri, Ni Luh Putu Rassri dan I Ketut Mustanda. 2014. "Pengaruh Struktur Modal, Kebijakan Dividen dan Keputusan Investasi terhadap Nilai Perusahaan". Fakultas Ekonomi dan Bisnis Universitas Udayana, Bali, Indonesia.

Ghozali, Imam. 2012. Aplikasi Analisis Multivariate dengan Program IBM SPSS 20. Semarang : Badan penerbit Univesitas Diponegoro.

Mardiyati, Umi et.al. 2012. "Pengaruh Kebijakan Dividen, Kebijakan Hutang, dan Profitabilitas terhadap Nilai Perusahaan”. Jurnal Riset Manajemen Sains Indonesia, Vol. 3, No. 1. 
Nurfaridah, Zulin. 2011. "Pengaruh Kebijakan Deviden, Kebijakan Hutang, dan Kebijakan Investasi terhadap Nilai Perusahaan Pada Industri Manufaktur yang Go Publik”. Skripsi, Sekolah Tinggi Ilmu Ekonomi Perbanas Surabaya.

Prapaska, Johan Ruth dan Siti Mutmainah. 2012. "Analisis Pengaruh Tingkat Profitabilitas, Keputusan Investasi, Keputusan Pendanaan, dan Kebijakan Deviden terhadap Nilai Perusahaan". Diponegoro Journal of Accounting, Vol. 1, No. 1, Hal 1-12.

Prasetyo, Dimas et.al. 2013. "Pengaruh Keputusan Investasi dan Keputusan Pendanaan terhadap Nilai Perusahaan”. Fakultas Ilmu Administrasi Universitas Brawijaya.

Rahmawati, Apriliana Nuzul. 2012. "Analisis Faktor Kebijakan Hutang yang Mempengaruhi Nilai Perusahaan". Skripsi, Fakultas Ekonomi dan Bisnis Universitas Diponegoro Semarang.

Rakhimsyah, Leli Amnah dan Barbara Gunawan. 2011. "Pengaruh Keputusan Investasi, Keputusan Pendanaan, Kebijakan Dividen, dan Tingkat Suku Bunga terhadap Nilai Perusahaan". Jurnal Investasi, Vol. 7, No. 1, hal. 31-45.

Wahyudi, Untung dan Hartini Prasetyaning Pawestri. 2006. "Implikasi Struktur Kepemilikan terhadap Nilai Perusahaan: dengan Keputusan Keuangan sebagai Variabel Intervening”. Simposium Nasional Akuntansi 9 Padang.

Wati, Ni Kadek Ari Lina dan Ni Putu Ayu Darmayanti. 2013. "Pengaruh Kepemilikan Manajerial dan Kinerja Keuangan terhadap Kebijakan Dividend an Nilai Perusahaan". Fakultas Ekonomi dan Bisnis Universitas Udayana, Bali, Indonesia.

Wijaya, Lihan Rini Puspo. 2010. "Implikasi Keputusan Investasi, Keputusan Pendanaan, dan Kebijakan Dividen terhadap Nilai Perusahaan". Tesis, Program Pascasarjana Fakultas Ekonomi Universitas Sebelas Maret Surakarta.

Wijaya, Lihan Rini Puspo dan Bandi Anas Wibawa. 2010. "Pengaruh Keputusan Investasi, Keputusan Pendanaan, dan Kebijakan Dividen terhadap Nilai Perusahaan". Simposium Nasional Akuntansi XIII Purwokerto. 